\title{
Access to Credit and Rice Production Efficiency of Rural Households in the Mekong Delta
}

\author{
Vuong Quoc Duy \\ College of Economics, CanTho University, Vietnam
}

Copyright (C) 2015 by authors, all rights reserved. Authors agree that this article remains permanently open access under the terms of the Creative Commons Attribution License 4.0 International License

\begin{abstract}
Rice production in the Mekong Delta region accounts for more than 50\% of Vietnam's total paddy production and $90 \%$ of its rice export volume. Therefore, increasing the efficiency of rice production systems and enhancing the comparative advantage of Vietnam's rice industry have been an important focus area for policy makers and researchers for many years. Access to credit has been identified as a key factor for improving rice production. This fact is validated in this study by considering the production and technical efficiency levels of rice production for a sample of farmers in the Mekong Delta. The study focuses particularly on the effects of both formal and informal credits on production levels and production efficiency by using a Stochastic frontier analysis and a quantile regression. By using the data from survey 300 rice production farmers in Mekong Delta in 2014, the results confirm the positive influence of credit on production and production efficiency. Both formal and informal credit appears to be important. The findings also imply that in order to improve the rice production outcomes, various possibles policy recommendation needed to be considered such as expansion of rura 1 credit systems, establishment more branches of agricultural and community banks, settlement the savings mobilization programmes and provision the "credit plus" services to the banks customers.
\end{abstract}

Keywords Stochastic Frontier Analysis, Quantile Regression, Access to Credit, Rural Households

JEL Classification: E5, G2, O2

\section{Introduction}

Since Vietnam launched its innovation policy in 1986, the government has recognized the significant role played by agriculture. It has liberalized rice and agricultural input markets and implemented policies to promote the cultivation of high-yielding crop varieties. Since then Vietnam has experienced a steady increase in rice production and exports.
Rice production reached 99 million tons in 2010 with rice yields of 5.32 tons/ha (GSO, 2010). The country has been a major rice exporter since 1989, currently among the top exporters in the world. In 2010, it exported as much as 6.88 million tons for 3.23 billion US dollars, up by $15.4 \%$ in volume and $21.2 \%$ from the previous year (GSO, 2010). These results were achieved with widely applied modern rice technology, resulting in the widespread adoption of high yielding modern rice varieties, whose use increased from $17 \%$ in 1980 to nearly $90 \%$ in 2000 (Ut and Kajisa, 2006, pp. 167-189).

The MD is recognized as the rice bowl of Vietnam and rice production is the main income source for farmers in the region. It accounts for more than $50 \%$ of the country's total paddy production and $90 \%$ of national rice export volumes (GSO, 2010). Yet not all farms seem to produce at their optimal level. There may possibly be room for improvement which could contribute to rural household income and continue to increase the comparative advantage of Vietnam's rice production. Credit access can be important in the further improvement of a farming system because of its ability to create access to other production factors (Oladeebo and Oladeebo, 2008, pp. 59-62). Rashid, et al. (2002) found that small farmers without credit in Bangladesh allocated less land to rice even when the magnitude of the effects of credit was very small. The availability of credit can affect fixed production costs (Brambilla and Porto, 2005) and farmers will use fewer seeds and fertilizer if they are credit constrained. Through its effect on production, output and covering marketing costs, credit may also influence farmers' participation in marketing systems and increase their ability to generate higher incomes.

This paper investigates the contribution of credit to rice production and technical efficiency levels. Credit is different from input subsidies or technology provision because it is not free and loans need to be repaid at maturity (CGAP, 2006), which is why lenders require collateral. Previous studies on rice production have been concerned with the importance of credit on productivity, whether through Stochastic Frontier Analysis (SFA) or Data Envelopment Analysis (DEA) approaches. It is hypothesized that rice 
production outcome in Mekong Delta have been affected by the access to credit through the proper approaches. In addition, access to credit may affect on the scale of rice production in given areas. This paper investigates whether the effect of credit on production levels by applying a quantile regression, and the influence of credit access on rice efficiency levels by using a stochastic frontier analyse. While descriptive analysis and the SFA have shown large differences in production and efficiency between borrowers and non-borrowers, it is not clear whether the positive effect is due to the access to credit or to differences in scale. The quantile regression confirms that credit contributes to production across the different production quantiles. This paper also distinguishes formal from informal credit in rice production functions.

\section{Literature Review}

Technical efficiency in agricultural (including rice) production has been widely studied (Coelli and Battese, 1996, pp. 103-128, Kyi and Oppen, 1999, Coelli, 2002, pp. 607-626, Rahman, 2003, pp. 408-503, Amaza and Maurice, 2005, Moses and Adebayo, 2007, pp. 20-30). Recently, Marty et al. (2015) studies the "Impact of credit on Technical Efficiency of Maize producing households in the Northern Ghana. By using the cross sectional data from 233 maize producing households and propensity score matching, the findings shown that credit impacted positively on farmer's technical efficiency. Provision of credit enhanced timelt purchases and efficient allocation of factors input to producethe maximum output. In addition, possible receommedation is that the credit programme of agricultural interventions shoud target several source poor farmers in order to enhance efficiency gains. The finanical institutions must collaborate with agricultural and farmer development projects to facilitate credit delivery to smallholder farmers. Moreover, Sossou (2014) investigated the relationship between rural credit and farms efficiency by using the data of 476 farmers in Benin. The stochastic frontier truncated normal with conditional mean model and Tobit model, the findings shown that decision to invest credit to purchase better quality of pesticides, herbicides, fertilizer and so forth. The positive effect of the scheme may be significant under condition of farmer's eduction level improvement. The efficiency score are reduced by household size and gender of the household head.

The study of "Economic efficiency of rice production in smallholder in irrigation schemes in Malawi", Magreta et al (2013) used a parametric frontier approach to analyze technical, allocative and economic efficiency of smallholder rice farmers. The findings shown that average technical, allocative and economic efficiency levels are $65 \%, 59 \%$ and $53 \%$, respectively. In addition, among others, access to credit has affected the efficiency levels of smallholder rice farmers. It is recommended that farmer groups or associations can play a significant role in ensuring that farmers get relevant technical advice, credit access as well as learn and share knowledge from each other in rice production efficiency.

In Vietnam, a number of studies have analysed rice production efficiency. Linh et al (2015) studied "Productive Efficiency of Crop Farms in Vietnam: A DEA with a Smooth Bootstrap Application". By using data of 300 farms households from 12 villages and the DEA and Tobit models, findings indicated that the age of head of household, the number of family, the national electricity source, the distance to the nearest market, and the access to credit, extension services and milling machines are the main factors affecting the technical and scale efficiency of rice and maize crops. The results suggested that expanding the national electricity source, emphasizing policies for adjusting customs and knowledge, using credit in appropriate ways and continuing to enhance extension services.

In addition, Khai and Yabe (2010) investigated the rice techinical efficiency in Vietnam by using the data of from General Statistic of Organization VHLSS (2005-2006). The findings demonstrated that the most signicant factors having positive influence on technical efficiency levels are intensive labor in rice cultivation, irrigation and education. Similarly, $\mathrm{Vu}$ (2007) study of the efficiency of Vietnamese rice farming households (based on both DEA and SFA) found that differences in technical efficiency could be explained by differences in length of education (as well as regional fixed effects). Chi and Yamada (2005) also calculated the technical efficiency of rice farmers in Can Tho province using a production frontier function. Their results suggest that the technical efficiency of rice production is significantly affected by the education level and technical knowledge of the household head/farmer and the inputs used. Nguyen (2003, pp. 325-357) studied the technical efficiency in the MD using a SFA. Findings revealed that the average technical efficiencies in the three growing seasons winter-spring, spring-summer and summer-autumn - are $86 \%, 79 \%$, and $80 \%$, respectively. Technical inefficiency was explained by variables such as land size, rice variety used, integrated pest management adoption, sowing techniques and availability of credit.

In this paper we break new ground by combining SFA and quantile regressions to analyze the contribution of credit to rice production efficiency and rice yields. And, as mentioned in the introduction, we suspect that scale economies may be involved. Some of the above-cited papers confirm that farm size matters for efficiency levels. This paper applies a quantile regression to check whether scale of production also has an effect on the role played by access to credit.

\section{Methodology}

\subsection{Research Questions}

As indicated in introduction, we have two major research 
questions. One of them is to find out whether the access to credit effects on the rice efficiency of households in Mekong Delta. We will examine the volatility of the access to credit on both rice technical efficiency and scale of return on rice production of the households in Mekong Delta.

\subsection{Modeling Volatility}

\subsubsection{Stochastic Frontier Analysis (SFA)}

SFA, originally proposed by Aigner, et al. (1977, pp. 21-37) and Meeusen and Vandenbroeck (1977, pp. 435-445) and modified by Jondrow, et al. (1982, pp. 233-238), is popular in determining farm efficiency levels for cross-sectional data. It specifies the relationship between output and input levels using two error terms. One error term is the traditional normal error term in which the mean is zero and the variance is constant. The other is the technical inefficiency level, expressed as a half normal, truncated normal, exponential or two parameter gamma distribution (Coelli, 1996a). The two error terms in the maximum likelihood estimation of the production function determine inefficiency levels.

In a SFA, output $Y_{i}$ is function of inputs $X_{i}$ as follows (Greene, 2008)

$$
Y_{i}=f\left(x_{i} ; \beta\right)+\varepsilon_{i}=f\left(x_{i} ; \beta\right)+\left(v_{i}-u_{i}\right) \quad i=1 \ldots . . N
$$

where: $Y_{i}$ is the production level (or log production) of the $\mathrm{i}$-th farm and $\mathrm{X}_{\mathrm{i}}$ is a $1 \times \mathrm{xK}$ vector of transformation of input quantities of the $\mathrm{i}$-th farm. The function $\mathrm{f}($.$) is typically a$ Cobb-Douglas production technology or translog technology. Both functional forms are used extensively in the literature (Thiam, et al., 2001, pp. 235-243). The forms of Cobb-Douglas and Translog can be expressed as follows (Van Passel, et al., 2009, pp. 3057-3069):

Cobb-Douglas function:

$$
\log \left(y_{i}\right)=\beta_{0}+\sum_{k=1}^{n} \beta_{k} \log \left(x_{i k}\right)+v_{i}-u_{i}
$$

Translog function:

$$
\begin{gathered}
\log \left(y_{i}\right)=\beta_{0}+\sum_{k=1}^{n} \beta_{k} \log \left(x_{i k}\right)+\sum_{k=1}^{n} \beta_{k k}\left(\log \left(x_{i k}\right)^{2}\right. \\
+\sum_{k=1}^{n} \beta_{k} \beta_{t}\left(\log \left(x_{i k}\right) \cdot \log \left(x_{i t}\right)\right)+v_{i}-u_{i}
\end{gathered}
$$

This paper assumes a Cobb-Douglas model. A translog specification would require a larger sample and may increase the probability of multicollinearity.

The error term in equation (1) is composed of two components (Aigner, et al., 1977, pp. 21-37):

$$
\varepsilon_{\mathrm{i}}=\mathrm{v}_{\mathrm{i}}-\mathrm{u}_{\mathrm{i}}
$$

where: $\mathrm{v}_{\mathrm{i}}$ is the symmetric component which it accounts for random variation in output due to factors outside the farmer's control such as weather and diseases and which is assumed to be independently and identically distributed with
$\mathrm{N}\left(0, \delta_{\mathrm{v}}{ }^{2}\right)$;

$\mathrm{u}_{\mathrm{i}}$ captures technical inefficiency in production and is also assumed to be an independently and identically distributed non-negative truncation of the $\mathrm{N}\left(\varphi, \delta_{\mathrm{u}}{ }^{2}\right)$ distribution. In this paper, we assume $u_{i}$ to be half-normal distributed as specified by Greene (2008).

SFA also allows the estimation of the determinants of the TE levels in an inefficiency model. The variable $u_{i}$, which estimates technical inefficiency of household, is regressed against the household's socio-economic characteristics $\mathrm{Z}$ as follows (Coelli, 1996b):

$$
u_{i}=\alpha_{0}+\sum_{i=1}^{n} \alpha_{i} Z_{i}
$$

The SF model enables us to estimate parameters and standard errors, and to test hypotheses by using the maximum likelihood method. The parameter vectors $\beta$ and $\delta$ are estimated together with the variance parameters $\delta^{2}=\delta_{v}^{2}+\delta_{u}^{2}$ and $\gamma=\delta_{u}^{2} / \delta^{2}=\frac{\delta_{u}^{2}}{\delta_{v}^{2}+\delta_{u}^{2}}$.

The Frontier 4.1 program written by Coelli, et al. (1998) is used for the SFA estimation in this paper.

\subsubsection{Quantile Regression}

The Cobb-Douglas model estimated in the SFA does not allow allocation for non-linearity in production scale. To check scale effects on production and to check if the effect of credit differs over production scale, a quantile regression is estimated. The quantile regression model was first introduced by Koenker and Bassett (1978, pp. 33-50) and was developed in Koenker and Hallock (2001, pp. 143-156). The $\theta^{\text {th }}$ quantile for random variables $\mathrm{X}$ is defined as the value $m_{\theta}$, such that the probability of $X$ is less than $m_{\theta}$. Mathematically this becomes (Koenker and Hallock, 2001, pp. 143-156):

$$
\Theta=\operatorname{Pr}\left[\mathrm{X} \leq \mathrm{m}_{\theta}\right]=\mathrm{F}\left(\mathrm{m}_{\theta}\right)
$$

which is the cumulative distribution function of $\mathrm{X}$. The value $\mathrm{m}^{\wedge}{ }_{\theta}$ for a sample quantile can be derived using the inverse of the cumulative distribution function, which is the quantile function $\mathrm{Q}(\theta)$, under the assumption of a strictly monotonic, continuous distribution function, namely (Koenker and Hallock, 2001, pp. 143-156):

$$
\mathrm{m}^{\wedge} \theta=\mathrm{F}^{-1}(\theta)=\mathrm{Q}(\theta)=\inf \{\mathrm{X} \in \mathrm{R}: 0 \leq \mathrm{F}(\mathrm{X} \theta)\}
$$

with $\inf \{\}$ defined as the greatest lower bound of $\mathrm{m}^{\wedge} \theta$. Therefore, the function $\mathrm{Q}(\theta)$ returns the lowest value for which the statement is true.

The term quantile model is used to distinguish between the number of equal size subsets used. For instance, four quantiles refer to quartile $(\theta=0.25 ; 0.5 ; 0.75$ and 0.95$)$ positions, dividing the data set into four equal-size groups. The 0.5 quantile is the median. 


\subsubsection{Model Specification}

Both the SFA and quantile models take rice production in tons (efficiency and yield) as the dependent variable. The independent variables considered for the Cobb-Douglas SFA model are the basic production factors: area under rice cultivation, expenditure on seed, fertilizer and pesticides, expenditure on hired labour and cost of hiring machines (table 1). Factors suspected to influence inefficiency levels (following the literature cited above) are household characteristics (age, gender, education level and experience of the head of household, family size and Vietnamese ethnicity), farm characteristics (use of new technology and access to amenities such as electricity), market orientation (percentage of sales and distance to the market centre), location and finally the uptake of formal or informal credit. The same variables are used in the quantile regression. The uptake of formal credit is reflected by a dummy variable that takes value one if the farmer has borrowed a sum from one of the financial institutions in the MD, and zero otherwise. A similar dummy variable reflects the uptake of informal credit.

\subsubsection{Data}

The data used in this paper is drawn from a household survey on living standards in Vietnam, the Vietnam Living Standard Survey - VLSS 2008. The survey was conducted by the General Statistical Office of Vietnam (GSO) in 2008, funded by United Nation Development Programme (UNDP) and Swedish International Development Cooperation Authority (SIDA) with technical assistance from the World Bank. It gathered information through community and household level questionnaires. The household questionnaires were organized into nine sections comprising basic demography, employment and labour force participation, education, health, income, expenditure, housing, fixed assets and durable goods, and participation in poverty reduction programmes.

The selection of the total sample of 45,945 households followed a method of stratified random cluster sampling of 3,063 communes/villages in Vietnam to make the data representative for national, rural and urban, and regional levels. The sample is divided into two subsamples: one sample with 9,189 households and another with 36,756 households (GSO, 2008). From the former sample, detailed information needed for household living standards analysis at national and regional levels were gathered; from the latter sample it was not.

As this paper focuses on rice production of households in the Mekong Delta, a subsample of 654 households in this region was selected from the 9,189 households. The criteria for selection were residence in the MD, production of rice and availability of sufficiently detailed information on this production. Included in the data is information on household characteristics, access to amenities, market orientation and very importantly, rice input and output levels (table 1).
Table 1. Variable definition and measurement

\begin{tabular}{|c|c|c|}
\hline Variables & Units & Definition \\
\hline Rice production $(\mathrm{Y})$ & Tons/hectare & Quantity of rice produced \\
\hline Area rice $\left(\mathrm{X}_{1}\right)$ & Hectare & Land area for rice planted \\
\hline Seeds $\left(\mathrm{X}_{2}\right)$ & Tons/hectare & Expenditure on seed \\
\hline Fertilizer $\left(\mathrm{X}_{3}\right)$ & Tons/hectare & $\begin{array}{c}\text { Total chemical fertilizer } \\
\text { used per hectare }\end{array}$ \\
\hline Pesticides $\left(\mathrm{X}_{4}\right)$ & $\begin{array}{c}\text { Million } \\
\text { dongs/hectare }\end{array}$ & $\begin{array}{c}\text { Expenditure on pesticides } \\
\text { per hectare }\end{array}$ \\
\hline Hired labour $\left(\mathrm{X}_{5}\right)$ & Hours/hectare & $\begin{array}{c}\text { Total houring labour hired } \\
\text { per hectare }\end{array}$ \\
\hline Family Labor $\left(\mathrm{X}_{6}\right)$ & Hours $/$ hectare & $\begin{array}{c}\text { Total family labor per } \\
\text { hectare }\end{array}$ \\
\hline
\end{tabular}

\section{Results and Discussion}

Table 2 compares the household and farm characteristics of borrowers and non-borrowers. There was no difference between both the groups in terms of age, farming experience and family size. The household heads of the borrower group have on average higher education levels. Rice production in the borrower group was significantly higher than that of non-borrowers. Borrowers planted more rice, and spent more on inputs for rice production such as fertilizers, pesticides and hired machinery than non-borrowers except for expenditure on seeds. Additionally, the household characteristics of borrowers and non-borrowers were not significantly different for any of the binary variables except the Vietnamese ethnicity and the adoption of new technology, where, not surprisingly, the percentage of adoption among borrowers was much higher (table 3 ).

Table 2. Household and farm characteristics of borrowers and non-borrowers

\begin{tabular}{|c|c|c|c|}
\hline $\begin{array}{c}\text { Independent } \\
\text { variable (N) }\end{array}$ & $\begin{array}{c}\text { Non-borrower } \\
\text { s (312) }\end{array}$ & $\begin{array}{c}\text { Borrowers } \\
\mathbf{( 3 4 2 )}\end{array}$ & t- test \\
\hline Age (years) & 50.00 & 52.00 & 1.32 \\
\hline Family size (persons) & 4.50 & 4.55 & -0.27 \\
\hline $\begin{array}{c}\text { Farming experience } \\
\text { (years) }\end{array}$ & 25.00 & 23.00 & 1.54 \\
\hline Education (years) & 8.90 & 8.80 & 0.49 \\
\hline $\begin{array}{c}\text { Rice production } \\
\text { (tons/ha) }\end{array}$ & 5.30 & 5.40 & -0.32 \\
\hline Area with rice (ha) & 22.70 & 30.80 & 1.37 \\
\hline Seeds (tons/ha) & 0.21 & 0.22 & $-1.70 *$ \\
\hline Fertilizer (tons/ha) & 0.21 & 0.20 & 1.23 \\
\hline $\begin{array}{c}\text { Pesticides } \\
\text { (mill.dongs/ha) }\end{array}$ & 5.11 & 4.97 & 1.31 \\
\hline Hired labour (hours) & 15.40 & 15.60 & -0.44 \\
\hline Family labor (hours) & 22.70 & 22.00 & 1.16 \\
\hline $\begin{array}{c}\text { Distance to market } \\
\text { centre (km) }\end{array}$ & 5.60 & 5.00 & $-1.84 * *$ \\
\hline
\end{tabular}

Notes: *,**,***: Significant at 10\%; 5\%; and $1 \%$.

Table 3. Household characteristics of borrowers and non-borrowers

\begin{tabular}{|c|c|c|c|}
\hline $\begin{array}{c}\text { Independent variables } \\
\mathbf{n}\end{array}$ & $\begin{array}{c}\text { Non-Borrowers } \\
\mathbf{1 4 6}\end{array}$ & $\begin{array}{c}\text { Borrowers } \\
\mathbf{1 5 4}\end{array}$ & $\mathbf{X}^{\mathbf{2}}$ Test \\
\hline Gender (\% male) & 80 & 82 & 0.22 \\
\hline New technology (\% yes) & 36 & 72 & $9.70 * * *$ \\
\hline $\begin{array}{c}\text { Can Tho province (\% } \\
\text { yes) }\end{array}$ & 23 & 22 & 0.41 \\
\hline
\end{tabular}

Notes: *,**,***: Significant at $10 \% ; 5 \%$; and $1 \%$. 
The sources and characteristics of credit are presented in table 4. Most borrowers (68.1\%) had taken out a loan from a formal financial institution (Vietnam Bank of Agriculture and Rural Development or Vietnam Bank Social Policy). About $31.4 \%$ of the borrowers had a loan from informal sources who were individual lenders, friends and relatives. The remaining $1.5 \%$ had a loan from semi-formal lenders such as job creation funds and social political associations. There was a difference between loan characteristics among providers. Average loans taken out from formal lenders were larger than those of the other credit sources. The informal lenders charged higher interest rates.

Table 4. Loan sources and characteristics

\begin{tabular}{|c|c|c|c|c|}
\hline $\begin{array}{c}\text { Loan } \\
\text { characteristics } \\
\text { /Source }\end{array}$ & Units & $\begin{array}{c}\text { Formal } \\
\text { sector }\end{array}$ & $\begin{array}{c}\text { Informal } \\
\text { sector }\end{array}$ & F-Test \\
\hline Loan size & Mill.dongs & 41.135 & 55.191 & 0.61 \\
\hline Interest rate & \%/year & 16 & 30 & -0.46 \\
\hline Maturity & months & 16 & 15 & $2.67 * *$ \\
\hline
\end{tabular}

Notes: $*, * *, * * *$ : Significant at $10 \% ; 5 \%$; and $1 \%$.

Table 5. Estimation of SFA and efficiency levels for rice production

\begin{tabular}{|c|c|c|c|c|}
\hline \multirow[b]{2}{*}{$\begin{array}{l}\text { Production } \\
\text { Coefficient }\end{array}$} & \multirow[b]{2}{*}{ Units } & \multicolumn{3}{|c|}{ SFA model } \\
\hline & & Co-efficient & $\begin{array}{l}\text { Standard } \\
\text { Deviation }\end{array}$ & t-ratio \\
\hline \multicolumn{5}{|l|}{$\begin{array}{c}\text { Dependent } \\
\text { variable: } \\
\text { Log(rice } \\
\text { outcome) (tons) }\end{array}$} \\
\hline \multicolumn{5}{|l|}{$\begin{array}{c}\text { Independent } \\
\text { variables }(\mathrm{Log}) \text { : }\end{array}$} \\
\hline Constant & $\beta 0$ & 0.650 & 0.137 & 1.292 \\
\hline Area rice & $\beta 1$ & 0.114 & 0.075 & -0.279 \\
\hline Seeds & $\beta 2$ & 0.180 & 0.123 & 0.399 \\
\hline Fertilizer & $\beta 3$ & 0.100 & 0.124 & 0.801 \\
\hline Pesticides & $\beta 4$ & 0.135 & 0.126 & 0.290 \\
\hline Hired labour & $\beta 5$ & 0.152 & 0.105 & 0.391 \\
\hline Family labour & $\beta 6$ & -0.193 & 0.104 & 0.014 \\
\hline$\delta 2$ & & 0.026 & 0.008 & 0.849 \\
\hline$\Gamma$ & & 0.016 & 0.121 & 0.131 \\
\hline Log Likelihood & & 10.246 & & \\
\hline \multicolumn{5}{|l|}{$\begin{array}{c}\text { Inefficiency } \\
\text { Effect Model }\end{array}$} \\
\hline Age & $\delta 1$ & -0.343 & 0.091 & -0.459 \\
\hline Family-size & $\delta 2$ & -0.401 & 0.060 & -1.418 \\
\hline Experiences & $\delta 3$ & -0.405 & 0.039 & -1.449 \\
\hline Education & $\delta 4$ & $0.132 * *$ & 0.068 & 1.976 \\
\hline Gender & $\delta 5$ & $-0.016 * *$ & 0.264 & -2.145 \\
\hline New technology & $\delta 6$ & $-0.089 * * *$ & 0.080 & -2.446 \\
\hline Formal credit & $\delta 7$ & -0.037 & 0.075 & -0.494 \\
\hline $\begin{array}{l}\text { Can Tho } \\
\text { province }\end{array}$ & $\delta 8$ & 0.096 & 0.231 & 1.133 \\
\hline $\begin{array}{c}\text { Distance to } \\
\text { market }\end{array}$ & $\delta 9$ & 0.060 & 0.119 & 1.121 \\
\hline 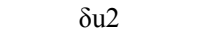 & & 0.002 & & \\
\hline$\delta \mathrm{v} 2$ & & 0.034 & & \\
\hline $\mathrm{TE}$ & & 0.931 & & \\
\hline $\begin{array}{l}\text { LR test of the } \\
\text { one sided error }\end{array}$ & & 301.423 & & \\
\hline
\end{tabular}

Notes: $*, * * * *$ : Significant at $10 \% ; 5 \%$; and $1 \%$.

Table 5 gives the results of the maximum likelihood estimates (MLE) of the pooled household model with dummy variables for the household who took formal and informal credit. The average technical efficiency of rice production was about $93 \%$. This implies that farmers still had the possibility to improve their efficiency by an average of $15 \%$. Similar results were found by Awotide and Adejobi (2006, pp. 107-113) and Nguyen (2003, pp. 325-357), although the calculated efficiency levels are relative to the frontier of the sampled households. In the Cobb-Douglas function, the coefficients of areas with rice and expenditure on pesticides were statistically significant.

The model indicated that technical inefficiency of rice production was associated with household characteristics (education level), technology (use of new farm technology), location (distance from households' dwelling place to market centre), and the Can Tho province and the access to formal or informal credit. This implies that rice efficiency was positively associated with better educated households using newer techniques, households from the Can Tho province and those further out from the market centre. Both formal and informal credit seems to increase farm efficiency. The coefficients of average age, family size, farming experience, Vietnamese ethnicity and gender of household head were not significant. The likelihood ratio tests of one-side generalized error exceeded the critical value ( $\alpha=5$ percent), suggesting that the null hypothesis of no technical inefficiency in rice production in the sample is rejected.

The distribution of technical efficiency of rural households in the MD is presented in table 7. The technical efficiency levels of borrowers were higher than those of non-borrowers.

Table 6. Distribution technical efficiencies of households

\begin{tabular}{ccccccc}
\hline \multirow{2}{*}{ Range } & \multicolumn{4}{c}{ Borrowers } & \multirow{2}{*}{ Non-borrowers } \\
\cline { 2 - 5 } & \multicolumn{2}{c}{$\begin{array}{c}\text { Formal } \\
\text { borrowers }\end{array}$} & \multicolumn{2}{c}{$\begin{array}{c}\text { Informal } \\
\text { borrowers }\end{array}$} & & \\
\hline & $\mathrm{n}$ & $\%$ & $\mathrm{n}$ & $\%$ & $\mathrm{n}$ & $\%$ \\
\hline$<70 \%$ & 0 & 0 & 0 & 0 & 57 & 39 \\
$70-80 \%$ & 0 & 0 & 0 & 0 & 28 & 19.20 \\
$80-90 \%$ & 0 & 0 & 15 & 31.90 & 27 & 18.50 \\
$90-100 \%$ & 107 & 100 & 32 & 68.10 & 34 & 23.30 \\
Total & 107 & 100 & 47 & 100 & 146 & 100 \\
\hline
\end{tabular}

Table 7 gives the results of the quantile analysis. The rice yields of all quantiles are significantly positively affected by the area with rice, expenditure on pesticides (except quantile 95), education level of the household head (except quantile 95) and use of new farming technology. Furthermore, for all quantiles, access to credit, both formal and informal, contributed significantly to production. The rice yield of quantile 50 was positively affected by age of the household head, Vietnamese ethnicity, higher expenditure on hired labour and location in Can Tho province. The coefficients of the dummy variables for access to formal and informal credit confirm that borrowers were more likely to have higher rice production outcomes than non-borrowers. The coefficients of formal credit uptake were larger than those for informal credit access in functions of quantile 25 and 95 , and smaller in functions of quantile 50 and 75 , but the differences were not large. 
Table 7. Quantile regressions of rice production

\begin{tabular}{|c|c|c|c|c|c|}
\hline & Units & Q25 & Q50 & Q75 & Q95 \\
\hline \multicolumn{6}{|l|}{$\begin{array}{l}\text { Dependent variable: } \\
\text { Rice (tons/ha) }\end{array}$} \\
\hline \multicolumn{6}{|l|}{ Independent Variables } \\
\hline \multirow[t]{2}{*}{ Ricearea } & $\beta_{1}$ & -0.001 & -0.001 & $-0.002^{*}$ & $-0.001^{* * *}$ \\
\hline & & $(-0.78)$ & $(-0.28)$ & $(-2.40)$ & $(-5.21)$ \\
\hline \multirow[t]{2}{*}{ Seed } & $\beta_{2}$ & 1.293 & 0.814 & -0.115 & $-0.626^{* * *}$ \\
\hline & & $(1.43)$ & $(0.34)$ & $(-0.09)$ & $(-7.89)$ \\
\hline \multirow[t]{2}{*}{ Fertilizers } & $\beta_{3}$ & 0.334 & 0.985 & -0.474 & $1.508^{* * *}$ \\
\hline & & $(0.30)$ & $(0.35)$ & $(-0.34)$ & (16.36) \\
\hline \multirow[t]{2}{*}{ Pesticides } & $\beta_{4}$ & 0.051 & 0.065 & -0.001 & $0.042^{* * *}$ \\
\hline & & $(1.19)$ & $(0.53)$ & $(-0.00)$ & $(10.91)$ \\
\hline \multirow[t]{2}{*}{ Hiredlabor } & $\beta_{5}$ & $0.043^{* *}$ & 0.043 & 0.013 & $0.003^{*}$ \\
\hline & & $(2.85)$ & $(1.16)$ & $(0.62)$ & $(2.06)$ \\
\hline \multirow[t]{2}{*}{ Familylabor } & $\beta_{6}$ & 0.001 & -0.009 & -0.006 & $0.00383^{* * *}$ \\
\hline & & $(0.04)$ & $(-0.36)$ & $(-0.44)$ & $(5.01)$ \\
\hline \multirow[t]{2}{*}{ Age } & $\beta_{7}$ & -0.004 & -0.009 & -0.001 & $-0.003^{* * *}$ \\
\hline & & $(-1.36)$ & $(-1.01)$ & $(-0.16)$ & $(-11.53)$ \\
\hline \multirow[t]{2}{*}{ Familysize } & $\beta_{8}$ & -0.007 & -0.0186 & 0.029 & -0.003 \\
\hline & & $(-0.29)$ & $(-0.28)$ & $(0.72)$ & $(-1.53)$ \\
\hline \multirow[t]{2}{*}{ Riceexperience } & $\beta_{9}$ & -0.004 & 0.001 & 0.003 & $0.003^{* * *}$ \\
\hline & & $(-1.19)$ & $(0.05)$ & $(0.52)$ & (10.19) \\
\hline \multirow[t]{2}{*}{ Education } & $\beta_{10}$ & -0.014 & 0.017 & 0.008 & $-0.017^{* * *}$ \\
\hline & & $(-0.96)$ & $(0.43)$ & $(0.36)$ & $(-13.24)$ \\
\hline \multirow[t]{2}{*}{ Gender } & $\beta_{11}$ & -0.075 & 0.021 & 0.078 & $-0.031^{* *}$ \\
\hline & & $(-0.60)$ & $(0.07)$ & $(0.44)$ & $(-3.24)$ \\
\hline \multirow[t]{2}{*}{ Newtech } & $\beta_{12}$ & $-0.390^{* * *}$ & -0.373 & -0.110 & $-0.103^{* * *}$ \\
\hline & & $(-3.95)$ & $(-1.52)$ & $(-0.84)$ & $(-13.37)$ \\
\hline \multirow[t]{2}{*}{ Formalcredit } & $\beta_{13}$ & $-0.180^{*}$ & -0.049 & -0.063 & $-0.105^{* * *}$ \\
\hline & & $(-2.16)$ & $(-0.21)$ & $(-0.47)$ & $(-14.05)$ \\
\hline \multirow[t]{2}{*}{ Cantho } & $\beta_{14}$ & $0.474^{* * *}$ & 0.324 & 0.120 & $0.075^{* * *}$ \\
\hline & & $(4.79)$ & $(1.28)$ & $(0.81)$ & $(-9.21)$ \\
\hline \multirow[t]{2}{*}{ Distancetomarket } & $\beta_{15}$ & -0.0131 & -0.013 & $-0.059^{* *}$ & $0.003^{*}$ \\
\hline & & $(-0.85)$ & $(-0.33)$ & $(-2.76)$ & $(2.58)$ \\
\hline \multirow[t]{2}{*}{ Cons } & $\beta_{0}$ & $4.615^{* * *}$ & $4.724^{* *}$ & $6.146^{* * *}$ & $6.072^{* * *}$ \\
\hline & & $(8.38)$ & (3.33) & $(7.92)$ & (137.07) \\
\hline$N$ & & 154 & 154 & 154 & 154 \\
\hline
\end{tabular}

Notes: t statistics in parentheses; *,**,***: Significant at $10 \% ; 5 \%$; and $1 \%$.

The possible explanations for the model results are as follows. First, the coefficients of access to formal credit were negatively significant in technical inefficiency regression and positively significant in the quantile regression, implying that access to credit is likely to increase the production and technical efficiency of rice farmers. In fact, the financial constraints in farming are likely to be relieved through credit, which allows the purchase of more inputs, which in turn increases revenues and profit (Hyuha, et al., 2007, pp. 243-253). Additional funds from credit markets can be used to invest in rice paddy production, principally by adopting new technologies (Nuryartono., et al., 2005). Nuryartono (2005) also found that access to financial markets facilitated the adoption of technology such as fertilizer and pesticides. In the inefficiency model, the coefficient of access to formal credit is larger than that of informal credit, suggesting that access to formal credit had effect on rice production efficiency. The findings are consistent with Kebede (2001), Nwaru (2001, pp. 1-10), Ajibefund and Aderinola (2003), Nguyen (2003, pp. 325-357), Ogundari (2008, pp. 224-233).

A second possible explanation is that the coefficients for 
education and use of new technique were negative and significant in the technical inefficiency model and positively significant in quantile regression (except in the largest quantile). Education may enhance the acquisition and utilization of information on improved technology as well as their entrepreneurship (Coelli and Battese, 1996, pp. 103-128, Dey, et al., 2000, pp. 33-46, Effiong, 2005, Onyenweaku, et al., 2005, pp. 20-25, Idiong, 2006). The importance of the introduction of new technologies on production is also confirmed.

Third, the signs in both models of the coefficient of distance from household dwelling to the market suggest that households in remote areas were more likely to have lower technical efficiency levels and rice yields. Poor communication and transportation facilities may lead to lower efficiency levels of households further away from market centre. This finding is consistent with those in studies by Lanzona and Evenson (1997), DeSilva, et al. (2006, pp. 851-865), Larson and Plessmann (2009, pp. 24-32).

Furthermore, farmers in Can Tho province had higher production and efficiency levels than those in the other provinces. Rice farming in this province benefits not only from the natural fertilization provided by the Tien and Hau rivers, but also from the support of the two largest agricultural science centres of the Mekong Delta, namely Can Tho University and Cuu Long Delta Rice Research Institute.

\section{Conclusions and Policy Recommendations}

This paper investigates the technical efficiencies and yields of rice farmers in the MD of Vietnam by using SFA and quantile regressions. The determinants of the stochastic production frontier tested included the land area used for rice and expenditure on seeds, hired labour, fertilizer, pesticides and hired machines. Coefficients of area with rice and of expenditure on pesticides had the expected signs (as they did in studies by Coelli and Battese (1996, pp. 103-128), Kyi and Oppen (1999), Wadud and White (2000, pp. 1665-1673), Jaforullah and Premachandra (2003), Nguyen (2003, pp. 325-357), Ogundari (2008, pp. 224-233)). Technical efficiency and rice yields were positively influenced by access to credit, household characteristics (educational level of household head), location of households (location in Can Tho province and proximity to the nearest market centre), farm technology (use of new farm technology and expenditure on pesticides) and area with rice. In addition, borrowers are relatively wealthier than non-borrowers, although the quantile regression confirmed that credit positively contributes to production among the smaller producers as well.

The results of this study have a number of implications, especially for credit accessibility.

- Access to formal credit had a larger effect on rice production efficiency than the uptake of informal credit.

- A further expansion of rural credit systems could enhance and contribute to increased rice production and efficiency in the Mekong Delta.

- Accessibility to credit by rural households could be improved by establishing more branches of agricultural and community banks in the rural areas, providing innovative credit schemes that overcome problems of smallholder farmers who lack collateral and by reducing the currently long processing times of loan applications and other requirements.

- Access to credit could be made easier for farmers without the specific commodity requirements. Furthermore, credit should meet the needs of the farmers, in particular for investment in farm activities.

- Savings mobilization programmes should be developed and promoted in the survey area, which will inspire participation and provide encouragement to farmers to save and reinvest. Savings programmes also reduce the costs of monitoring lenders.

- The financial institutions to facilitate or directly involve themselves in "credit plus" services that may include skill development/training, marketing facilities and business development services for their customers to help them sustain the economic activities supported by their financial schemes.

- A future research project should focus on the impact of external services intervention on rice farming by panel data.

\section{REFERENCES}

[1] Aigner, D. J., Lovell, C. A. K., Schmidt, P., 1977. Formulation and estimation of stochastic frontier production function models, Journal Economics 6, 21-37.

[2] Ajibefund, I. A., Aderinola, A., 2003. Determinants of technical efficiency and policy implications in traditional agricultural production: empirical study of Nigerian food crop farmers, Work in progress report presented at the bi-Annual research Workshop of AERC, May 24-29th, Nairobi Kenya.

[3] Awotide, D. O., Adejobi, A. O., 2006. Technical Efficiency and Cost of production of Plantain farmers in Oyo State, Nigeria, Moor Journal of Agricultural Research. 7, 107-113.

[4] Brambilla, I., Porto, G. G., 2005. Farm Productivity and Market Structure: Evidence From Cotton Reforms in Zambia, Access on 29/03/2012 at:

http://www.depeco.econo.unlp.edu.ar/semi/semi030605.pdf

[5] CGAP, 2006. Commercial Loan Agreements A Technical Guide for Microfinance Institutions, Consultative Group to Assist the Poor Prepared for CGAP by Cleary, Gottlieb, Steen \& Hamilton, LLP.

[6] Chi, T. T. N., Yamada, R., 2005. Assessing the technical efficiency of input rice production in Thoi Lai Commune, Co Do district, Can Tho City, Omonrice.

[7] Coelli, T. J., 1996b. Guide to FRONTIER Version 4.1: A 
Computer Program for Stochastic Frontier Production and Cost Function Estimation, , CEPA Working Paper 96/7. Armidale NSW Australia., Department of Econometrics, University of New England.

[8] Coelli, T., 1996a. A Guide to FRONTIER Version 4.1: A Computer Program for Stochastic Frontier Production and Cost Function Estimation. Centre for Efficiency and Productivity Analysis, University of New England, Armidale, NSW, 2351, CEPA Working Paper 96/07.

[9] Coelli, T., Rao, D. S. P., Battese, G. E., 1998. An introduction to efficiency and productivity analysis, , Kluwer Academic Publishers, Boston/Dordrecht/London.

[10] DeSilva, S., Evenson., R. E., Kimhi., A., 2006. Labor Supervision and Institutional Conditions: Evidence from Bicol Rice Farms, American Journal Agricultural Economics $88,851-865$.

[11] Dey, M. M., Paraguas, F. J., Bimbaa, G. B., Ragaspi, P. B., 2000. Technical efficiency of tilapia growth out pond operations in the Philippines, Agricultural Economics and Management 4, 33-46.

[12] Effiong, E. O., 2005. Efficiency of production in selected livestock enterprises in Akwa Ibom State, Nigeria., Unpublished PhD Dissertation. Michael Okpara University of Agriculture, Umudike. .

[13] Greene, W. H., 2008. Econometric Analysis, in 6th ed. ed. New Jersey: Prentice Hall.

[14] GSO, 2010. General Statictics Office: Statistical Yearbook of Vietnam 2009 (in Vietnamese), Statistical Publishing House, Hanoi.

[15] Hyuha, T. S., Bashaasha, B., Nkonya, E., Kraybill, D., 2007. Analysis Of Profit Inefficiency In Rice Production in Eastern And Northern Uganda, African Crop Science Journal 15, 243-253.

[16] Idiong, I. C., 2006. Evaluation of technical, allocative, and economic efficiencies in rice production systems in cross river state, Nigeria. , Unpublished Ph.D Dissertation. Michael Okpara University of Agriculture, Umudike.

[17] Idiong, I. C., 2007. Estimation of Farm Level Technical Efficiency in Small Scale Swamp Rice Production in Cross River State of Nigeria: A Stochastic Frontier Approach, World Journal of Agricultural Sciences 3, 653-658.

[18] Jaforullah, M., Premachandra, E., 2003. Sensitivity of technical efficiency estimates of estimation approaches: An investigation using New Zealand dairy University of Otago, Economics Discussions Papers 0306. New Zealand.

[19] Kebede, T. A., 2001. Farm household technical efficiency: a stochastic frontier analysis a study of rice producers in Mardi-Watershed in the Western Development Region of Nepal, Master Thesis, Agricultural University of Norway.

[20] Koenker, R., Bassett, G., 1978. Regression Quantiles, Economitrica. 46, 33-50.

[21] Koenker, R., Hallock, K. F., 2001. Quantile Regression, Journal of Economic Perspectives 15, 143-156.

[22] Kyi, T., Oppen, M. V., 1999. Stochastic Frontier Production Function and Technical Efficiency Estimation: A case study on irrigated rice in Myanmar, Deutscher Tropentag 1999 in Berlin, Session: Sustainable Technology Development in
Crop Production.

[23] Lanzona, L. A., Evenson, R. E., 1997. The Effects of Transaction Costs on Labor Market Participation and Earnings: Evidence from Rural Philippine Markets, Center Discussion Paper No. 790. Economic Growth Center: Yale University.

[24] Larson, D. F., Plessmann, F., 2009. Do Farmers Choose To Be Inefficient? Evidence from Bicol, Journal Development Economics 90, 24-32.

[25] Meeusen, W., Vandenbroeck, J., 1977. Efficiency Estimation From Cobb-Douglas Production Functions With Composed Error, International Economics Reviews 18, 435-445.

[26] Moser, S. C., 2005. Impact assessment and policy response to sea level rise in three US states: An exploration of human dimention uncertainties, Global Environmental Change 15.

[27] Moses, J., Adebayo, A. F., 2007. Efficiency of Factors Determining Rainfed Rice Production in Ganye Local Government Area, Adamawa State, Journal of Sustainable Development in Agriculture and Environment. 3, 20-30.

[28] Nguyen, T. M. H., 2003. A Study on Technical Efficiency of Rice Production in The Mekong Delta-Vietnam by Stochastic Frontier Analysis, Journal of the Faculty of Agriculture Kyushu University. 48, 325-357.

[29] Nguyen, T. M. H., 2003. A Study on Technical Efficiency of Rice Production in The Mekong Delta-Vietnam by Stochastic Frontier Analysis, Journal of the Faculty of Agriculture Kyushu University 48, 325-357.

[30] Nuryartono, N., 2005. Impact of Smallholders' access to Land and Credit Markets on Technology Adoption and Land Uses Decision: The Case of Tropical Forest Margins in Central Sulawesi Indonesia. $\mathrm{PhD}$ Thesis, Insitute of Rural Development, George August University of Goettingen.

[31] Nuryartono., N., Zeller., M., Schwarze., S., 2005. Credit Rationing of Farm Households and Agricultural production: Empirical Evidence in the Rural Areas of Central Sulawesi, Indonesia. Institut of Rural Development. Georg August University of Goettingen, Tropentag 2005 Stuttgart-Hohenheim, October 11-13, 2005

[32] Nwaru, J. C., 2001. Gender and Relative Production Efficiency in Food Crop Farming in Abia State of Nigeria, The Nigerian Agricultural Journal. 34, 1-10.

[33] Ogundari, K., 2008. Resource-productivity, allocative efficiency and determinants of technical efficiency of rainfed rice farmers: A guide for food security policy in Nigeria, Agricultural Economics 54, 224-233.

[34] Oladeebo, J. O., Fajuyigbe, A. A., 2007. Technical Efficiency of Men and Women Upland Rice Farmers in Osun State, Nigeria, Journal of Human Ecology 22, 93-100.

[35] Oladeebo, J. O., Oladeebo, O. E., 2008. Determinants of Loan Repayment among Smallholder Farmers in Ogbomoso Agricultural Zone of Oyo State, Nigeria, Journal Social Science 17, 59-62.

[36] Onyenweaku, C. E., Igwe, K. C., Mbanasor, J. A., 2005. Application of a stochastic frontier production function to the measurement of technical efficiency in yam production in Nasarawa State, Nigeria, Journal of Sustainable Tropical Agricultural Research 13, 20-25. 
[37] Rashid, S., Sharma, M., Zeller, M., 2002. Micro-lending for small farmers in Bangladesh: Does it affect farm households' land allocation decisions?, MSSD Discussion Paper 45, International Food Policy Research Institute. .

[38] Thiam, A., Bravo-Ureta, B. E., Rivas, T. E., 2001. Technical efficiency in developing country agriculture: A meta-analysis, Agricultural Economics 25, 235-243.

[39] Van Passel, S., Van Huylenbroeck, G., Lauwers, L., Mathijs, E., 2009. Sustainable value assessment of farms using frontier efficiency benchmarks, Journal Environmental Managment 90, 3057-3069.

[40] Vu, L. H., 2007. Efficiency of Rice Farming Households in Vietnam: A DEA with Bootstrap and Stochastic Frontier Application, Mimeo, Department of Applied Economics, University of Minnesota.

[41] Wadud, A., White, B., 2000. Farm household efficiency in Bangladesh: A comparison of stochastic frontier and DEA methods, Applied Economics 32, 1665-1673.

[42] Ut, T. T., Kajisa, K., 2006. The impact of Green Revolution on rice production in Vietnam, Development Economics 44, 167-189.

[43] Magreta, R., Edriss A.K., Mapemba, L., and S. Zingora. (2013). Economic Efficiency of Rice Production in Smallholder Irrigation Schemes: A Case of Nkhate Irrigation Scheme in Southern Malawi. Invited paper presented at the $4^{\text {th }}$ International Conference of the African Association of Agricultural Economist, September 22-25, 2013, Hammamet, Tunisia.

[44] Truong Tuan Linh, Teruaki Nanseki and Yosuke Chomei. (2015). Productive Efficiency of Crop Farms in Viet Nam: A DEA with a smooth Bootstrap Application. Journal of Agricultural Science, Vol.7, No.5, 2015. (ISSN 1916-9752) E-ISSN 1916-9760.

[45] Comlan Herve Sossou, Freddy Noma and Jacob a Yabi., (2014). Rural credit and Farms Efficiency: Modelling Farmers Credit Allocation Decision, Evidences from Benin. Economics Research International Volume 2014 (2014), Article ID 309352, 8 pages http://dx.doi.org/10.1155/2014/309352 